\title{
BUILDING BRIDGES AND CROSSING BOUNDARIES: PHILOSOPHY, THEOLOGY, AND THE INTERRUPTIONS OF TRANSCENDENCE
}

\author{
PHILIP J. ROSSI \\ Marquette University
}

\begin{abstract}
Discussions about theological realism within analytic philosophy of religion, and the larger conversation between analytic and continental styles in philosophy of religion have generated relatively little interest among Catholic philosophers and theologians; conversely, the work of major figures in recent Catholic theology seems to evoke little interest from analytic philosophers of religion. Using the 1998 papal encyclical on faith and reason, Fides et ratio, as a major point of reference, this essay offers a preliminary account of the bases for such seeming mutual indifference and offers some suggestions for future dialogue.
\end{abstract}

In this essay, I will be offering three points of reference from which to locate current philosophical discussions of theological realism with respect to another set of substantive discussions about the relation between philosophy and theology that have been taking place since the middle of the twentieth century. The goal for doing so is to raise the larger question of how philosophers and theologians representing a range of divergent intellectual traditions can constructively engage one another in mutual conversation. My main focus will be on the discourse and idioms regarding faith, reason, and religion that have been characteristically used by most Catholic philosophers and theologians since at least the late nineteenth century establishment of Thomism as paradigmatic for their inquiry. One of my specific purposes here is to provide an initial account of why these modes of Catholic philosophical and theological inquiry have been, for the most part, more observers (and often not particularly attentive ones) rather than participants in 
efforts by analytic and continental philosophers of religion to enter into productive conversation with one another as well as in their concomitant efforts to engage in conversation with theologians. My hope is that the points offered here will indicate that attention to these markers may help to delimit key parts of the larger conceptual and historical territories on which philosophy and theology have engaged - and in some cases failed to engage - one another in 'high modernity' and its aftermath. It will be my suggestion that taking account of the orientations these markers provide upon these Catholic conversations can help to construct pathways leading to an enlarged and, one hopes, more productive encounter between philosophy and theology.

The first marker is Pope John Paul II's encyclical, Fides et ratio, 'On the Relationship Between Faith and Reason'. I consider it a fortuitous circumstance that this conference on 'Philosophical Perspectives on Theological Realism' is taking place just a few days prior to the fifteenth anniversary of the publication of this document on September 14, 1998. Fides et ratio provides an important basis from which those who, like myself, locate their work within the ambit of the long traditions of Roman Catholic philosophical and theological inquiry may enter into a renewed and perhaps even reconfigured engagement with fundamental questions about the multi-layered set of conceptual, methodological, and historical relations between the two disciplines. As I will propose in more detail later, not the least of the reasons for the significance of Fides et ratio as a marker for orienting engagements between philosophy and theology is that it takes further steps along the road that Gerald McCool had described, almost a decade earlier, as leading from 'unity to pluralism' in the internal evolution of the Thomism that had become, by the late nineteenth century, the officially sanctioned benchmark for Roman Catholic philosophical and theological inquiry. ${ }^{1}$ In particular, though this document still affirms pride of place to philosophical reflection articulated in continuity with Aquinas's modes of inquiry and thinking, it offers 'room at the table' for other - though not all - modes of philosophical thinking. ${ }^{2}$ How much room it allows, and for whom,

${ }^{1}$ Gerald A. McCool, SJ, From Unity to Pluralism: The Internal Evolution of Thomism (New York: Fordham University Press, 1989).

${ }^{2}$ Fides et ratio, $₫ 59, \S 74$. The former section briefly mentions and commends the views of a number of the philosophers who are then identified by name in the latter section; see also $\$ 76$. 
remain open questions that have a major bearing how to chart the scope and direction of future conversations between philosophers and theologians that more directly involve modes of discourse and inquiry rooted in these Catholic intellectual traditions.

The second marker is, I suspect, considerably less widely known, though it does bear directly on the conversation between analytic and continental modes of doing philosophy of religion. It comes from a panel discussion that took place at the 1993 Annual Meeting of the American Academy of Religion, the largest academic society in the Englishspeaking world for the multi-segmented field of religious studies. This panel was convened to explore the differences between 'philosophy of religion' as it is practiced and presented by two groups of scholars with different primary venues of academic dissemination of their work, one at the annual meetings of the American Academy of Religion, the other at the annual meetings of the American Philosophical Association. The four panel presentations from that session, supplemented by four invited contributions, were subsequently published in a concise volume, still available from Oxford University Press, titled God, Philosophy, and Academic Culture. ${ }^{3}$ In addition to trying to characterize from a variety of conceptual grids the differences between these two approaches to philosophy of religion - a task complicated by the fact that there are levels of overlap between the two groups - the participants in the discussion also paid some attention to historical and socio-cultural factors in each group that play a role in shaping different styles of argumentation, topics considered of central importance, and views about the function of this field of philosophical inquiry both in the academy and in the wider dynamics of culture.

While there are number of elements in these essays that would be quite useful to explore, there are at least two that I consider particularly significant for my purposes in this essay: the first is that even though the discussants agree that one major difference roughly follows the 'analytic/ continental' fault line, that is not the only difference of consequence they identify. ${ }^{4}$ The second is that some of those other differences seem to have their source in matters that are not extensively discussed in the

${ }^{3}$ Ed. William J. Wainwright (Atlanta: Scholars Press, 1996).

${ }^{4}$ Philip Quinn's essay, 'The Cultural Anthropology of Philosophy of Religion', pp. 4757 in God, Philosophy, and Academic Culture, imaginatively cast as a description of the 'tribal' practices of each group of philosophers, is especially instructive on this point. 
essays, the most important of which may very well be what I will call the unarticulated theological 'registers' that give to the work done on each side of the fault line a distinctive 'tonality' with respect to its possibilities for engaging various forms of Christian theological discourse. These tonalities, moreover, are themselves indicative of differences with respect to how participants in each group understand and engage the lifeworlds' of religious believers and their communities - and, increasingly important in 'a secular age', how they might engage the 'life worlds' of non-believers and the religiously indifferent. ${ }^{5}$ As I will note in more detail latter, there is an important formal similarity here to how I will analyze the import of Fides et ratio in that attention needs to be paid to what that document does not fully articulate, particularly with respect to engaging analytic philosophy of religion; in this case, the important unarticulated presuppositions of the document bear upon the substance and grammar of its own philosophical and theological anthropology, as well as what it takes to be the operative counterparts of such anthropology in its enlarged range of philosophical interlocutors.

The third marker is intended to provide a sense of the 'place from which' Fides et ratio has moved prior Catholic philosophical and theological discourse to the opening it has now provided for engaging a wider range of philosophical conversation partners. The marker I offer here is biographical inasmuch as the philosophical and theological education I received through the mid-1960s through the mid-1970s, as well as my subsequent experience as a philosopher who has been part of a theology faculty for close to four decades, represents in concrete terms key points of the arc that plots the intellectual trajectory taken in Fides et ratio from polemic to dialogue. This journey starts from a Thomistic-scholastic mode of discourse that was energetically renewed in the nineteenth century and that could be simultaneously triumphalist and defensive it its idiom and moves to a late twentieth century readiness to engage constructively with at least some of the other philosophical idioms it had once looked upon with deep suspicion.

My starting point for locating this point of reference is a remark that a fellow Jesuit, a scientist some twenty years my senior, made to me during the spring of 1971 before I started doctoral studies in philosophy

${ }^{5}$ The distinction I am making here is between those who have, in one way or another, opted not to believe and those for whom religious belief does not enter into their 'social imaginary'. 
at the University of Texas. From a previous conversation he was aware that one reason for my decision to seek an advanced degree in philosophy was a belief that, in the long run, it might be more useful than a degree in theology for helping to address the issues in theological ethics that then seemed to be most central. ${ }^{6}$ He now wanted to know why I thought that the program in philosophy at Texas was suitable for what I was hoping to do in the future; I said to him that it had a reputation for being one of the few philosophy departments in the United States that seemed to be intentionally seeking to foster productive exchange between analytic and continental ways of doing philosophy, and that being part of that kind of exchange might be instructive for my future purposes. Part of his response to me was something to the effect that I should be careful not to become too engaged with that 'analytic stuff' - a remark uttered with a tone of concern that carried an implication that not too far down the analytic road lay the slippery slope going from scepticism to unbelief. His response was not totally a surprise to me, since it resonated with the adversarial tonality with which the forms of Thomist-scholastic philosophy taught in Catholic seminaries and universities since at least the late nineteenth century had treated all the philosophy it took to issue from Descartes' fatal mistake of turning toward the cogito. In consequence, they all were thought eventually to lead to one or another of the 'isms' - subjectivism, materialism, relativism, idealism, pantheism, and ultimately atheism - that oppose the integral truth about humanity,

${ }^{6}$ There was vigorous discussion at the time over the question of the distinctiveness of Christian ethics, particularly with respect to philosophical ethics, a debate well summarized in James Gustafson's 1975 book, Can Ethics Be Christian? (Chicago: University of Chicago Press, 1975). There are resonances between that discussion and the revival of discussion about the possibility and the nature of 'Christian philosophy', for which one marker is the founding of the Society of Christian Philosophers in 1978. It is of note that this organization does not endorse any particular understanding of 'Christian philosophy', in that its membership 'is open to anyone interested in philosophy who considers himself or herself a Christian. Membership is not restricted to any particular "school" of philosophy or to any branch of Christianity, nor to professional philosophers.' (<http://www.societyofchristianphilosophers.com>, accessed July 24, 2013). An alternative set of perspectives on Christian philosophy, that places it in the context of earlier discussions of the issue among (mostly) European Catholic philosophers and theologians, can be found in The Question of Christian Philosophy Today, ed. Francis J. Ambrosio (New York: Fordham University Press, 1999). Key issues in all these discussions, in my judgment, are embedded in the larger phenomena of secularity that are described and analyzed in Charles Taylor's A Secular Age (Cambridge: Harvard University Press, 2007). 
the cosmos, and God that reason, guided by the light of faith, is capable of discerning.

Though the concerns of my elder Jesuit colleague might have been later alleviated by the fact that in the course of doctoral studies my work did not take an 'analytic turn' - or at least not a full one - that work did go in a direction that, by the standards of the adversarial Thomisms of the mid-twentieth century was undoubtedly worse: it turned in the direction of Immanuel Kant. It would not directly serve the purpose of this essay to rehearse in detail the intriguing history of the more than two centuries of Catholic engagement with Kant and his intellectual heritage. ${ }^{7}$ What is likely to be important, however, for our purposes, is an awareness that what I have argued for elsewhere as possibilities for a far less adversarial Catholic engagement with $\mathrm{Kant}^{8}$ have emerged as at least a partial consequence of a greatly enriched understanding of the historical and cultural contexts out of which such a confrontational dynamic towards Kant developed as part of a larger Catholic response of resistance in various forms and at various levels, to 'modernity' and 'enlightenment.' Attention to such historical and cultural contexts can be helpful for moving the mode of conversation from polemic to dialogue.

Let me now offer a more detailed look at these markers. I will concentrate on the first two, since the biographical one is, to a large degree, embedded within the dynamics at work in each of them. As already noted, the focus will be upon matters that, even though they are of importance in providing conditions for productive conversation

7 For a wide-ranging account of this engagement see the essays in Kant und der Katholizismus: Stationen einer wechselhaften Geschichte, ed. Norbert Fischer (Freiburg: Verlag Herder, 2005).

8 See Philip J. Rossi, 'Reading Kant from a Catholic Horizon: Ethics and the Anthropology of Grace', Theological Studies, 71 (2010), 79-100; 'Finite Freedom, Fractured and Fragile: Kant's Anthropology as Resource for a Postmodern Theology of Grace', Philosophie et théologie: Festschrift Emilio Brito, SJ, Bibliotheca Ephemeridum Theologicarum Lovaniensium, 206, ed. Éric Gaziaux (Leuven: Peeters Press, 2007), pp. 47-60; 'Reading Kant through Theological Spectacles', Kant and the New Philosophy of Religion, ed. Chris L. Firestone and Stephen R. Palmquist (Bloomington: Indiana University Press, 2006), pp. 107-123; 'Die Bedeutung der Philosophie Immanuel Kants für die gegenwärtige katholische Theologie in den Vereinigten Staaten von Amerika', in Fischer, Kant und der Katholizismus, pp. 441-460.

9 A growing body of historical scholarship examining 'Catholic Enlightenment' is showing that Catholic engagement with various currents of enlightenment thought and culture was by no means uniformly one of resistance. See A Companion to the Catholic Enlightenment in Europe, ed. Ulrich L. Lehner and Michael Printy (Leiden: Brill, 2010). 
across these different idioms, are given, at best, only cursory attention in the two texts that I have referenced.

With respect to Fides et ratio, the most obvious matter of importance given little attention is the very heritage and practice of the forms of 'analytic philosophy' that by the mid-twentieth century had became a powerful idiom for philosophical discussion in the English speaking world and were starting to gain world-wide intellectual influence. ${ }^{10}$ At one level, the absence of extensive engagement is not surprising, given that the larger intellectual trajectory out of which this document emerged only occasionally engaged that idiom and, when it did so, was more often than not in a polemical mode. ${ }^{11}$ Fides et ratio moves in general consonance with the trajectory set out in the nineteenthcentury revival of Thomism that resulted in an official approbation, in Leo XIII's encyclical, Aeterni patris (1879), of the work of Aquinas as a touchstone for the mutual engagement of philosophy and theology and that then launched an energetic outpouring of historical, textual, systematic, and polemical studies of Thomas and Thomism that has continued for more than a century. ${ }^{12}$ Armed with the internal assurance of being philosophia perennis, there was little urgency for much of neoThomism to engage philosophical idioms other than its own, even as it focused on fierce internal disputes about which of its own schools of interpretation could lay the strongest claim to represent the thought of Thomas Aquinas authentically. ${ }^{13}$ With respect to analytic philosophy in particular, moreover, it was perceived as a philosophical idiom that, inasmuch as it worked along epistemic and metaphysical trajectories that

${ }^{10}$ One allusion can be found in $\$ 84$ in which there is mention of 'analysis of language'.

${ }^{11}$ Perhaps most notably in a BBC radio debate from 1948 on the existence of God that took place between Frederick C. Copleston, SJ and Bertrand Russell.

${ }^{12}$ Important elements of this are laid out by Gerald A. McCool, Catholic Theology in the Nineteenth Century: The Quest for a Unitary Method (New York: Seabury Press, 1977). A particularly notable irony is that the historical work that was given major impetus by this official approbation of Thomas eventually showed considerable difference between Thomas's own teaching and the views put forth in his name by many of the important nineteenth century proponents of the Thomistic revival.

${ }^{13}$ An important exception to this was the work of the Belgian Jesuit, Joseph Maréchal, whose five volume major work, Le point de départ de la métaphysique: leçons sur le développement historique et théorique du problème de la connaissance, Bruxelles: L'Édition universelle (Paris: Desclée, De Brouwer, 1944-1949), intentionally engaged the work of Kant in a constructive manner and resulted in the distinctive style of 'transcendental Thomism', which had a significant impact on mid-twentieth century Catholic theology, most notably in the work of Karl Rahner, SJ. 
diverged considerably from Thomistic realism, offered little prospect for constructive engagement, let alone convergence. It was seen as the heir of an empirical tradition that understood the human person and its relation to the world in ways, such as Hume's radical scepticism about the continuity of personal identity or the anthropological presuppositions about human motivation taken to be characteristic of utilitarianism, that provided little space for an openness of the human spirit to the reality of a transcendent God.

As McCool's work on the history of neo-Thomism indicates, by the midtwentieth century such a dynamic of insularity was no longer sustainable; Fides et ratio may thus be considered as representing a new dynamic that makes dialogue as well as polemic a legitimate form for Catholic philosophy and theology to engage other forms of philosophical inquiry and discourse. The encyclical envisions that the range of conceptual idioms and philosophical grammars with which Catholic philosophers and theologians may now engage in constructive conversation now stretches beyond the ambit of the varieties of Thomism that held almost exclusive primacy as interlocutors until the last third of the twentieth century. It opens new lines for discussion of the relationships between philosophy and theology that engage, in a positive spirit, a range of philosophical idioms and methods considerably wider than had usually been allowed by prior parameters for such conversation - parameters that too often showed more alacrity for identifying adversaries to be refuted than for providing conditions for mutually respectful and enlightening exchanges over both commonalities and genuinely deep differences. Yet, neither analytic philosophy nor any of its major expositors is explicitly included as one of these new interlocutors, let alone as a potentially significant one. ${ }^{14}$

Analytic philosophy's perceived difference from - and even opposition to - the epistemic and metaphysical trajectories in consonance with the expanded Thomistic horizon that the encyclical affirms seems to be the central factor in its lack of engagement with the extensive work in philosophy of religion (or, alternately, philosophical theology) that has been done in the analytic mode since the last quarter of the twentieth

${ }^{14}$ With the exception of John Henry Newman ( $\left.\$ 74\right)$, no Anglophone philosopher or theologian is mentioned by name in the encyclical. A further indication that little attention is given to the traditions of English language philosophy is that pragmatism is dismissed as 'an attitude of mind, which in making its choices, precludes theoretical considerations or judgments based on ethical principles' (\$89). 
century. Yet I think there is a significant additional factor that contributes to this lack of engagement, namely, what was mentioned above as the unarticulated theological 'registers' in which that work has often been done. I think it is at least arguable that, with the notable exception of the attention paid to Aquinas and other prominent medieval thinkers, particularly with respect to the doctrine of God, as well as to Christology, the 'theological register' in which much of this work is set has been keyed to concerns that have more typically preoccupied various streams of Christian theology issuing from the reformation - most notably those in a Calvinist/Reformed mode - rather than Catholic theology. I also think that a case might be made for a connection between these two factors, inasmuch as one long standing line of Catholic apologetic with respect to the Reformation and its theological inheritance has been to trace the source of its theological errors back to the epistemological and metaphysical principles and presuppositions of late medieval nominalism, of which the traditions of British empiricism are taken to be the heir. ${ }^{15}$

A case in point is that, while a number of Catholics (a notable example would be the late Philip Quinn) have been prominent participants from the outset in the revival of analytic philosophy of religion and philosophical theology, the impact of that revival upon Catholic theology seems to have been marginal. There are, it must be noted, regional differences here: e.g. Catholic philosophers and theologians working in the academic context of the UK have been proportionately more likely to be familiar with and work within the idioms of analytic philosophy (e.g., Elizabeth Anscombe, John Haldane, Gerard Hughes, Fergus Ker, Janice Martin Soskice, Denys Turner) than their counterparts in the US. One index of this is that a perusal of the programs from the most recent meetings of the Catholic Theological Society of America gives little indication that, save in a few highly specialized areas, the guild of Catholic theologians in the United States sees any urgency for theological engagement either with the general methods of analytic philosophy or the range of work produced by analytic philosophers of religion. ${ }^{16}$ Similarly, in the meetings and publications of the American

${ }^{15}$ A version of this argument appears in Brad S. Gregory, The Unintended Reformation: How a Religious Revolution Secularized Society (Cambridge: Harvard University Press, 2012).

16 There is an instructive set of essays, Hermes and Athena: Biblical Exegesis and Philosophical Theology, ed. Eleanore Stump and Thomas P. Flint (Notre Dame: University 
Catholic Philosophical Association, though there has recently been more engagement with the methods and representative key works of analytic philosophy and the list of recent presidents includes some notable analytic philosophers (Linda Zagzebski (1997) and Eleanore Stump (2000)), the predominant philosophical idiom represented in its work remains the ramified discourse of a Thomism expanded and enriched primarily by engagement with a variety of historical and contemporary idioms of continental philosophy and to a much lesser degree with the idioms of analytic philosophy.

Conversely, engagement with the key works of major Catholic twentieth century theologians such as DeLubac, Rahner, Von Balthasar, or Lonergan, has rarely been a prominent focus of attention for the work of analytic philosophers of religion. I don't think that the reason for this at best oblique intersection with Catholic theology on either side lies principally in the fact that analytic philosophical methods have not found their way into the conceptual/linguistic 'toolbox' of most Catholic theologians, nor that these Catholic theologians employ theological grammars resistant to analytic parsing. I think that what has been, so far, only occasional peripheral engagement has had at least as much to do with the fact that the prominent sets of issues that have been at stake in analytic discussions - for instance, in addition to questions about the existence and attributes of god, there are those that cluster around the dynamics of sin, grace, redemption as these intersect with the epistemic and volitional structure and dynamics of the human condition (a major concern of the work of Alvin Plantinga) - have been set in a register more resonant with the theological agendas and theological anthropologies of the Reformation than with some of the important pre- or postReformation Catholic alternatives. Another set of issues, clustering around topics such as the divine attributes, arguments for God's existence, aspects of Christology, and theodicy, do intersect more directly with discussions that have been prominent loci in Catholic philosophical and theological discourse. These issues are pertinent as elements of what is termed 'fundamental theology', which in recent eras of Catholic theology has served as a locus of transition from philosophy to theology in which

of Notre Dame Press, 1993), that illustrate some of the methodological and interpretative challenges that arose from an effort to engage biblical scholars (most of whom work from a Catholic theological context) with analytic philosophers of religion. Part of the challenge and the irony of these exchanges is that the majority of participants consider themselves Christian believers. 
one concern has been the articulation of apologetic arguments. ${ }^{17}$ It is important, however, to note that there are exceptions in which there has been more engagement with analytic idioms, among the most notable being the work of David Burrell, who has been an important Catholic interlocutor on issues such as divine agency and divine freedom. ${ }^{18}$

Paying attention to what I have termed the theological registers that are implicit in the work of analytic philosophers of religion - and conversely to the implicit (as well as the explicit) philosophical registers in the work of Catholic theologians - offers, I believe, an initial strategy for surveying useful paths along which to link the intellectual territory delimited by the marker that is (textually) represented by Fides et ratio and that delimited by the marker represented by the discussions in God, Philosophy, and Academic Culture. At the same time, however, it is quite important to be attentive to some other families of philosophical idioms - or, to return to a spatial image, to some other philosophical territories - that so far have tended to stand in inchoate, tentative and/ or uneasy relationships with both the idioms of analytic philosophy and the idioms of Catholic philosophy and theology delimited in Fides et ratio. Two of the other idioms clearly significant in this regard can be found, first, in the discourses of so-called post modernity, particularly with respect to their attentiveness to the contingency and finitude of the human condition, and, second, in the discourses of both reflective and practical engagement with the religious and cultural plurality that is deeply embedded in the human condition.

I would thus like to conclude by offering some brief considerations about each of these and their importance for shaping future conversations between philosophy and theology. My proposal here is that one important dimension of their significance lies in the extent to which they are allowed to function as disruptive idioms - or, perhaps more modestly, as idioms of surprise and de-centring - that require both analytic philosophy of religion and Catholic philosophy and theology

${ }_{17}$ An additional factor for the absence of full engagement seems to lie in the fact that there has been a distinctive institutional Catholic academic culture of higher education in the United States that has provided a context both for the maintenance of distinctive styles of Catholic philosophy and for measured engagement with the styles characteristic of the 'secular academy'.

${ }^{18}$ See, for instance, Freedom and Creation in Three Traditions (Notre Dame: University of Notre Dame Press, 1993); Knowing the Unknowable God: Ibn-Sina, Maimonides, Aquinas (Notre Dame: University of Notre Dame Press, 1992). 
to reexamine the adequacy of our own settled ways of speaking - or not speaking - of the divine and how we stand in our humanity in relation to the divine.

As already noted, Fides et ratio gives, at best, scant attention to the idioms of analytic philosophy but it does pay greater notice, though little of it positive, to modulations of the philosophical idioms that have emerged as an explicit engagement with the aftermath of modernity. ${ }^{19}$ It also takes note, in generally more positive fashion, of the importance of engaging the philosophical dimensions that are operative, both as implicit and as reflectively articulated, in human cultural and religious diversity. ${ }^{20}$ Yet the direction of its discussion of all of these idioms suggests that whatever positive value they have to bring to an engagement with the authoritative tradition(s) of Catholic philosophy and theology is to be measured by its consonance with that which the tradition already has fully and adequately in its possession. In this regard, even though Fides et ratio does not speak in the highly adversarial tonality in which neoThomism was often expressed, the scope of the plurality it allows and, in my view, the scope of what it sees as possible for Catholic philosophy and theology to learn from a robust engagement with plurality - and its potential for surprise or even disruption - remains circumscribed and hedged with great caution. With particular reference to issues of theological realism, moreover, it is important to note that the encyclical's affirmation of theological realism uses 'metaphysics' as a key term within its own idiom to express that caution and that it links a still strongly Thomist understanding of metaphysics to the possibility of affirming the transcendent reality that Christians name God. ${ }^{21}$ Put in somewhat different terms, the encyclical does not seek to articulate a defence of theological realism, since it takes such realism simply as a given for the theological enterprise.

Yet there is a way in which Fides et ratio acknowledges (ironically in my judgment) the disruptive value of the 'post-modern': This is in the extent that these idioms are, often by intent, in deconstructive dissonance to both the tonality and the substance of the intellectual traditions of the

$19 \$ \$ 46-47,55-56,61,81,84,90-91$ contain allusions and references to some of the elements that characterize a number of the forms of 'post-modern' philosophy. See Philip J. Rossi, SJ, 'After Fides et Ratio: New Models for a New Millennium', Philosophy \& Theology, 12 (2000), 419-431.

${ }^{20} \$ \$ 70-72,95$.

${ }^{21} \$ \$ 83-85$. 
modernity that formed the context for their emergence. ${ }^{22}$ In this regard, the encyclical is ready to enlist this dissonance as an ally for its own criticism of modernity. ${ }^{23}$ At the same time, it resists the force of such dissonance as it might apply to its own locutions and pays little heed to the high demands this idiom makes for listening with an ear trained to discern the interstices and the interruptions that arise within its own locutions from silence, the unsaid, and the absence of the said. In consequence, Fides et ratio all too readily hears in the idioms of postmodernity only the monotone bleakness of nihilism or the cacophonies of relativisms. To that extent they can be all too readily dismissed as the latest - and among the least attractive - variants of high modernity; and in their most ironic forms they could be argued to display an 'exclusive anti-humanism' that stands as the shadow side of what Charles Taylor has described as modernity's 'exclusive humanism'.

Along with Fides et ratio, analytic philosophy of religion has often had notable reservations about the idioms of post-modernity and (perhaps to lesser degree) the idioms of religious and cultural plurality though from conceptual and cultural bases that only partially overlap those operative in the judgments the encyclical makes. In some of these reservations there is, for instance, an engagement with issues articulated in terms of 'metaphysics', but there are significant differences from the encyclical in the operative construal of that term and its appropriate function in both philosophical and theological discourse. ${ }^{24}$ As the essays in God, Philosophy, and Academic Culture almost all note these idioms of post-modernity and plurality have been far more frequently heard among those whose stand on the 'continental' side of the fault line dividing the discourses of philosophy of religion in Anglophone academic culture. In the two decades that have passed since the AAR session that engaged the differences between the two styles of philosophy of religion there seems

${ }^{22}$ In this, the encyclical offers an instance of one of the alliances that Charles Taylor sees as characteristic of 'the three, perhaps ultimately, four-cornered battle' in modern culture, in this case an alliance in which 'neo-Nietzscheans and acknowledgers of transcendence are together in their absence of surprise at the continued disappointments of secular humanism ... ' ('A Catholic Modernity?', Dilemmas and Connections (Cambridge: Harvard University Press, 2011), p. 180).

$23 \$ 91$.

${ }^{24}$ Some of these particular differences have their sources, not surprisingly, in the extent to which one views the various modern criticisms of 'metaphysics' as successful or not. 
to have been some reorientations on both sides that have made possible more passages back and forth from different places along some of the major and minor fault lines. ${ }^{25}$ The essays identify a number of intellectual and cultural factors that, particularly in retrospect, seem to have started to have an impact in this regard. ${ }^{26}$ At the risk of oversimplification, let me suggest that what links a number of these factors is that, in a variety of ways, they exhibit the pressure of an insistent plurality that resists the deep and equally persistent human drive to closure that Susan Neiman has perceptively articulated in her treatment of 'sufficient reason. ${ }^{27} \mathrm{Put}$ in more historical terms, the plurality that has become an insistently present dynamic in our global, interdependent, multi-cultural and multi-religious world has entered into challenging and potentially deeply creative play with the human drive to make comprehensive sense of things that Kant gestured toward in identifying it as human reason's 'natural tendency (Naturanlage) to metaphysics.'.

My reference to Kant is offered to suggest that, in seeking to engage the discourses of post-modernity and of religious and cultural plurality, both the long predominant idioms of Catholic philosophy and theology and many of the idioms of analytic philosophy of religion are posed with a range of challenges to the nature and the status of the systemic presuppositions on which they each operate. To put this challenge in Kantian terms, the challenge is the extent to which those presuppositions are more appropriately characterized and function as 'constitutive' or as 'regulative'. Put in a post modern idiom, the challenge is the extent to which dissonance, interruption, and fragmentation are to be recognized as bearing at least equal significance in efforts to make sense of the cosmos and of ourselves as are the harmony, continuity, and unity that are markers of systemic thought. Put in the idiom of religious and cultural plurality, the challenge is the extent to which the living traditions of reflective discourse and practice from Asia, the global South, and indigenous

${ }^{25}$ Interest in Kierkegaard from both sides seems to be one marker of this; see C. Stephen Evans, 'On Taking God Seriously: Philosophy of Religion in the APA and the AAR', in God, Philosophy, and Academic Culture, p. 69.

${ }^{26}$ For on overview that attends to a number of these developments, see William Wood, 'On the New Analytic Theology: or the Road Less Travelled', Journal of the American Academy of Religion, 77 (2009), 941-960.

27 Susan Neiman, Evil in Modern Thought: An Alternative History of Philosophy (Princeton: Princeton University Press, 2002), pp. 314-328.

${ }^{28}$ Immanuel Kant, Prolegomena to any Future Metaphysics $₫ 60$, AA 4: 362-365. 
cultures now require those of us whose intellectual traditions have made us accustomed to heed, first and foremost, imperatives of systemic (and often monologic) unity, now need to attend far more carefully to plurality and otherness on its own terms as emergent from these life worlds. I would also like to suggest that such attention to interreligious and cross cultural plurality and otherness might make possible more productive and respectful attention to the historical plurality within our own traditions of philosophical and theological discourse as they have emerged (and continue to emerge) from the life worlds of the Christian East as well as the Christian West. ${ }^{29}$

I have tried to indicate in these concluding considerations that there is much value for our philosophical and theological enterprises if we take seriously the interruptive challenge that the idioms of postmodernity and of religious and cultural plurality pose to the systemic character of our enterprises; i.e., that aspect of our disciplines in which we labour to construct coherent and comprehensive patterns of meaning into which to fit all the different elements of our inquiry - and the life worlds that give rise to the inquiry in the first place. This is a challenge to which I believe we will have to pay attention once we attach significant weight as I think we should - to post-modern idioms that express the deep fractures that run all the way down the contexts from which we humans seek to exact meaning, and to idioms of interreligious and intercultural engagement that articulate difference and otherness as constitutive in our efforts to shape meaning.

These idioms remind us how deeply fracture, difference, and otherness run down through ourselves as finite seekers of such meaning. We need to consider, as philosophers and theologians, the extent to which these fractures have methodological consequences upon the way we conceive of and conduct our inquiries precisely as systemic enterprises. If we do so, we may then be in a position to articulate, in a way appropriate to what Charles Taylor has described as the 'fractured horizons' of modernity and its aftermath, a 'methodological modesty' (and perhaps also a 'metaphysical modesty') about what the systemic character of our enterprises may yield as finally ordered comprehensiveness on behalf of human efforts to render the world - and ourselves as part of that world - intelligible. Such 'methodological modesty', moreover,

29 This suggests that Christian ecumenism and interreligious engagement share a fundamental challenge with respect to religious otherness. 
may provide an important context from which we could then properly grapple with the questions about whether and how we, and the world of which we are a part, can stand as it is and move forward toward what it ought to be only by our standing in relation to a transcendent Other that (freely) constitutes us in the finite otherness and the differences of the radical contingency of dependence to which Christian discourse has given the name 'Creation'.

Acknowledgment. This paper was originally presented in Mainz, Germany, at a conference for the Analytic Theology Project, generously funded by the John Templeton Foundation. 